\title{
Effect of problem-solving based methods on critical thinking and academic achievement of math among students of saravan higher education centers
}

\author{
Azizollah Nosrat ${ }^{1 *}$, Abdulhamid Parsafar ${ }^{2}$ \\ ${ }^{1}$ Department of Applied Mathematics, Saravan Branch, Islamic Azad University, Saravan, Iran \\ ${ }^{2}$ Department of Educational Sciences, Saravan Branch Islamic Azad University, Saravan, Iran \\ *Corresponding author E-mail: nosrat@mail.iausaravan.ac.ir
}

\begin{abstract}
The aim of the present study is to determine the impact of problem-solving based methods on critical thinking and academic achievement of math in students of higher-education centers in the second semester of academic year 2013-14, Saravan city. The research method in this study is quasi-experimental, with the control group as well as pre-test and post-test. The study population includes all students in the second semester of 2013-14 who studied math in higher-education centers of Saravan city whose number was 400 and 130 students were selected as statistical samples. Measuring instruments used in this study were a researcher made academic achievement of math test and Watson-Glaser critical thinking test. To give an approximation of the content validity of the tests, analyzing books contents and comparing it with the extent of usage for conceptual questions, tests content validity was assured to some extent. The reliability of the test was calculated using bi-section method that according to the figures obtained for pre-test and post-test respectively $(\mathrm{r}=0.71$ and 0.68$)$, tests have an acceptable and relatively high reliability. To analyze the data, t-test was used. The results showed that academic achievement of math and critical thinking in the test group, compared to the control group were higher and the differences between their means were significant.
\end{abstract}

Keywords: Academic Achievement of Math; Critical Thinking; Mathematics; Problem-Solving Based Methods.

\section{Introduction}

In fact, problem-based teaching is a kind of preparing students for life, because life means facing with problems and attempts to understand and solve them. In problem-based teaching, activities and educational events are designed and arranged in such a way that a problem is created in mind of students, and they are interested to do efforts and find a solution for it. Problem-based method may be implemented individually or in groups [1].

In problem solving method, the underlying assumption is that access to knowledge is only possible through overcoming the process of problem solving or research. Accordingly, throughout teaching, students are placed in situations that they scientifically and exploratory take actions to solve it when facing with a new problem or issue. After identifying the problem or issue, they think about it. To this end, they collect and classify information and in their mind, they come to some conjectures and social solutions to solve the problems. Then they test their hypotheses in the arena of action and provide enough evidence to prove or disprove them. Finally, the argued hypothesis is accepted as a solution and the results will be generalized to similar cases. During the problem solving, learner achieves a set of learning and thinking skills [2]. Critical thinking and problem solving in nature are the same things, and both are a variety of human thought. However, they differ from each other partly. According to Seifert (1991), critical thinking is mostly related to the thinking process, while problemsolving is mostly concerned with the products or the result of thinking. Seifert also said about the two mental activities, usually, but not always critical-thinking deals with open issues, but problem-solving often deals with issues, which have single and clear answers. Dembo (1994) for critical thinking used deductive reasoning to analyze a mystery and for problem-solving exemplified a math or chemistry problem. Furthermore, critical thinking in addition to problem solving has some elements of the evaluation as well. Despite the high disputes, many educational psychologists, including Seifert (1991) sees these two mental skills so similar that he proposed the same learning process for them [3].

Chat Myers believes that methods of teaching critical thinking in different fields are different, and they must be developed in various ways, teaching critical thinking to students didn't include exchange of information, but rather include training views to analyze and understand information [4].

Critical thinking is like other skills. Each has his own style and his own capabilities, but all can achieve it by getting informed and teach it. In the past, we learned how to remind content to have better understanding and memorability; but now we know that memorizing the material is useless for the thoughts and minds and does not help to understand the information. Watson-Glaser [5] believes that the critical-thinking ability is processing and evaluation of previous data with new ones and outcome and result of the combination of deductive and inductive reasoning with the process of problem solving. Watson-Glaser definition of critical thinking was a basis to test critical thinking, which is nowadays widely used to measure critical thinking and is acceptable to the majority of scholars in various disciplines.

Magnussen et al [6] examined the effect of research-based teaching on critical thinking ability and showed that learners who re- 
ceived lower scores in Glaser Critical Thinking Test Form A, received higher scores after training.

Young Blood and Beitz [7] in their empirical research on nursing students showed that the use of active methods of teaching caused growth of their critical thinking.

Garside [8] performed an experimental study with a pretest and post-test on students and tried to answer this question, whether group discussions promote critical-thinking skills more than traditional training methods such as lectures and results indicated that there is no significant difference between the two training methods The use of constructivism-based teaching methods for eleven weeks in the educational psychology course increased students' critical-thinking skills [9].

From the perspective of Norris, critical-thinking ability is not widespread among students, and they earn no-good scores in tests, which evaluate assumption's detection ability, evaluating the arguments and inferences. Anderson and Smith clarified that elementary students can take passing score in the exam for photosynthesis, but they don't know that plants produce their own food (quoting from Marzano et al. [10]).

Myers believes that the growth and development of intellectual skills of students today had taken a critical state because the output, and the information of society are beyond the critical-thinking ability about the information, so that in recent years, educationalists have expressed concern about the disability of students in critical thinking.

Shabani and Mehrmohammadi [11] also have done another research with the subject: the effect of problem solving as a group on critical thinking of fourth-grade students of elementary schools in Tehran in experimental science, the results showed: on the one hand, problem solving method as a group activity, confirms comments and analysis of many scholars and plays an important role in fostering critical-thinking skills, and on the other hand, it is a guideline for the majority of teachers in providing opportunities for strengthening thinking especially critical thinking of students even in the early years of education.

Shabani [12] in his study showed that problem-solving as a group has a positive effect on the growth of critical thinking skills in the fourth grade students.

Critical thinking skills of nursing students of Semnan at different levels is in the range of 12-11 which has been almost one third of the test score of California Critical Thinking. The scores obtained by students in the United States and Korea is higher than the average scores, and it seems that the Iranian nursing students' scores are less than students in other countries [13].

In general, the results and findings all indicate the weakness of traditional methods of learning, especially high cognitive levels of Bloom's taxonomy and in addition, do not provide ground for the growth of levels of thinking such as problem solving, creative thinking and critical thinking.Research done on the problem-based approach and its impact on improving learning and academic achievement have shown that by improving academic achievement, students' motivation to learn will be increased. Seif [14] argues that learners interested in a subject, compared with lowinterested learners gain more success and the success will increase their level of interest and motivation toward the subject and similar issues. Research reports mentioned in the section on problembased education research have emphasized the significant increase of academic achievement. In other words, since comparing traditional methods and problem-solving based methods, academic achievement is used as one of the most important dependent variables, the results and findings also suggest improving student achievement in problem solving-based methods. So far, it was stated that there are many reasons why a problem-solving approach can make a significant contribution to the outcome of mathematics education. This approach is not only a means to development of logical thinking, but also it can create a platform for students for learning math, it can increase transferring skills to unfamiliar situations and is aesthetic per se. A problem-solving approach can provide a means for students to make their ideas about math and take responsibility for their own learning. No doubt mathematical program can be better extended through the creation of an environment in which students are taught by problem-solving approach.

Walsh and Paul [15] stated that critical thinking is a skill that may enhance or progress in any individual, however, critical thinking is not what associated with people growth, but it has to be taught. For believers of educability, critical thinking is the most basic assumption that the learners can think better and learning centers teach them how to do it.

So, this study using the teachings of psychology of problemsolving thinking and following the experimental approach to training mathematical problem-solving, considered its effects on critical thinking and academic achievement of math among students of higher-education institutions in Saravan city.

\section{Materials and methods}

Due to the nature of the subject matter, and other characteristics of this research, this study is implemented with quasi-experimental study and using pre-test, post-test in two groups: control group and test group. In this study, the effects of problem-solving based methods (independent variable) and critical thinking and academic achievement of math are (dependent variables). The study statistical population includes all students who have been studying in the second semester of academic year 2013-14 in Saravan higher education centers and selected math whose number was about 400 . Frequency distribution of statistical sample of this study is presented in Table (1).

\begin{tabular}{llllll}
\multicolumn{5}{c}{ Table 1: Distribution of Statistical Sample } \\
\hline $\begin{array}{l}\text { Group } \\
\text { University }\end{array}$ & $\begin{array}{l}\text { Control } \\
\text { Gender }\end{array}$ & \multicolumn{5}{c}{$\begin{array}{l}\text { Test } \\
\text { Gender } \\
\text { Male }\end{array}$} & Female & Male & Female & $\begin{array}{l}\text { Total } \\
(\mathrm{N})\end{array}$ \\
& 28 & 12 & 27 & 13 & 80 \\
IAU & 8 & 12 & 9 & 11 & 40 \\
PNU & 17 & 13 & 15 & 15 & 60 \\
HEC & 53 & 37 & 51 & 39 & 180 \\
Total & 90 & & 90 & & 180 \\
& & & & &
\end{tabular}

\subsection{Sample and sampling method}

The sampling method used in this research was a cluster random sampling. Since there are three higher-education centers (Islamic Azad University, Payam Noor University, Higher Education Complex) in Saravan, so from each university two classes were selected; one as test and the other as control, which eventually six classes were chosen as samples. Three classes in the control group $(n=90)$ and three classes within the test group $(n=90)$ i.e. the sample size was 180 .

\subsection{Research tools}

1) To perform the "pre-test" - "post-test," the teacher-made test academic achievement of math was used. To give an approximation of the content validity of these tests, researchers studied and analyzed the educational materials and number of pages and books and compared it with the percentage of use of any material questions, it content validity was assured. The reliability of problem-solving ability tests or the pre-test and post-test of mathematics were calculated using bisection method that according to figures obtained for the pre-test and post-test respectively $(r=0.71$ and 0.68$)$ tests proved to have an acceptable and relatively high reliability.

2) The other tool is students' critical-thinking questionnaire. This questionnaire has been made by Watson-Glaser consisting of five sub-components (test) that measures students' critical thinking. 


\subsection{Procedure}

In the beginning, to establish peer groups of test and control groups, the mean scores of students from previous semesters were used. At the beginning of the semester, critical-thinking questionnaire was completed by students in both control and test groups, and their tendency to critical thinking was recorded. In the next session, pre-test questions were distributed and tested in both groups. Then, traditional method of teaching was continued in the control group until the end of the term, but in the test group from the first session, the class was divided into groups of five, and each of the groups was asked to choose a name for their group, so the groups were formed with the specific identity and researcher at each session raised issues that can involve students with subject matters and students talk with each other, and then presented answers in writing. During the 10 weeks of training, various samples ranging from issues of books were raised for the students, and they discussed in their group, and then answers were written on the blackboard for public and each group presented their argument pro and against the answers. At the end of the semester, academic achievement of math test (post-test) and Watson - Glaser critical thinking questionnaires in both groups were performed.

It is worth mentioning the solved sample problems during classes were selected from book exercises and issues given for homework were used from sample questions of previous semesters. As It was mentioned, since the teacher of both classes was the same, in a coordination with him, the sample exercises used for the tes group were individually used for the control group, although these exercises alone, without the use of teaching problem-solving skills were transferred to the control group.

\section{Results}

\subsection{First hypothesis}

H0: problem-solving based methods compared to conventional traditional methods has no effect on academic achievement of math among students.

H1: problem-solving based methods compared to conventional traditional methods has a greater impact on academic achievement of math among students.

To test this hypothesis, independent t-test and dependent t-test was used. The results are presented using Tables (2).

Table 2: Results of Statistical Analysis of Levine's Test for Scores of academic achievement of math in Test and Control Groups in the Pre-Test

\begin{tabular}{lllll}
\hline Variable & Group & Number & F & Sig \\
\hline \multirow{2}{*}{ academic achievement of math } & Test & 90 & 1.22 & 0.26 \\
& Control & 90 & & \\
\hline
\end{tabular}

Table 3: Mean Differences of Academic Achievement of Math in Test and Control Groups in Pre-Test

\begin{tabular}{llllllll}
\hline Variable & Group & Number & Mean & SD & T & DF & Sig \\
\hline $\begin{array}{l}\text { academic } \\
\begin{array}{l}\text { achievement } \\
\text { of math }\end{array}\end{array}$ & Test & 90 & 11.97 & 3.12 & & & \\
\hline
\end{tabular}

In order to compare the academic achievement of math test scores in both groups was tested using independent t-test. Levine test results in Table (2) are from $(0.05<0.26=$ levene's $p)$ stating that the variances in academic achievement of math test scores are equal in both control and test groups. Assuming equal variances, according to t-test results in Table (3) as the level of significance of the error is smaller $0.05(0.05>0.000)$. So between mean achievement test scores of the control and test groups with the $\mathrm{t}=$ 13.5 there is a significant statistical difference between the control group of educational attainment is higher.

In order to compare the academic achievement of math test scores in both groups were tested using independent t-test. Levine test results in Table (2) are from $(0.05<0.26=$ levene's $p)$ stating that the variances in achievement test scores are equal in both control and test groups. Assuming equal variances, according to t-test results in Table (3) as the level of significance of the error is smaller $0.05(0.05>0.000)$. So between mean academic achievement of math test scores of the control and test groups with the $13 / 5=\mathrm{t}$ there is a significant statistical difference between the control group of educational attainment is higher.

Table 4: Results of Statistical Analysis of Levene Test for Scores of academic achievement of math in the Test and Control Groups for Post-Test

\begin{tabular}{lllll}
\hline Variable & Group & Number & F & Sig \\
\hline Academic achievement of math & Test & 90 & 0.92 & 0.33
\end{tabular}

Table 5: Differences in Mean Scores of Academic Achievement of Math in Test and Control Groups for Post-Test

\begin{tabular}{lllllll}
\hline Variable & Group & Number & Mean & SD & T & DF Sig \\
\hline Academic achievement of Test & 90 & 12.59 & 3.25 & & \multirow{2}{*}{23.4} & 1780.000 \\
math & Control & 90 & 10.59 & 3.07 & & \\
\hline
\end{tabular}

In order to compare the academic achievement of math pre-test scores in both test and control groups, independent t-test was used. Levene test results in Table 3 (Levene's $p=0.5>0.33$ ) states that the variance of academic achievement of math $t$ pre-test scores are equal in control and test groups. Assuming equal variances, according to t-test results in Table (5), as the level of significance is smaller than 0.05 error level $(0.05>0.000)$. So there is a statistically significant difference between the mean scores for academic achievement of math pre-test in both control and test groups with $t$ $=4.23$ and the control group had a higher academic achievement of math.

Table 6: Differences in Mean Scores of Academic Achievement of Math for Pre-Test and Post-Test

\begin{tabular}{|c|c|c|c|c|c|c|c|}
\hline Group & Variable & Test & $\mathrm{N}$ & $\mathrm{M}$ & SD & $\mathrm{T}$ & DF Sig \\
\hline \multirow{2}{*}{ Test } & \multirow{2}{*}{$\begin{array}{l}\text { Academic achievement } \\
\text { of math }\end{array}$} & Pre- test & 90 & 11.97 & 3.12 & \multirow{2}{*}{-2.83} & \multirow{2}{*}{890.006} \\
\hline & & Post-test & 90 & 12.59 & 3.25 & & \\
\hline \multirow{2}{*}{ Control } & \multirow{2}{*}{$\begin{array}{l}\text { Academic achievement } \\
\text { of math }\end{array}$} & Pre- test & 90 & 9.67 & 2.88 & \multirow{2}{*}{-3.61} & \multirow{2}{*}{890.000} \\
\hline & & Post-test & 90 & 10.59 & 3.07 & & \\
\hline
\end{tabular}

In order to compare pre-test and post-test scores of academic achievement of math in test group, dependent t-test was used. Since the level of significance is smaller than 0.05 error level $(0.05>0.006)$, so there is statistically a significant difference between the mean score of the pre-test and post-test of academic achievement of math in the test group with $t=-2.83$, by observing mean, the mean pre-test score is more than post-test scores.

In order to compare pre-test and post-test scores of academic achievement in the control group, dependent t-test was used. Since the level of significance is smaller than 0.05 error level $(0.05>$ 0.006), so there is statistically a significant difference between the mean score of the pre-test and post-test of academic achievement in the control group with $t=-3.61$, by observing mean, the mean pre-test score is more than post-test scores.

According to the results, that both in the pre-test and post-test there is a significant difference in both control and test groups, we conclude that the problem-solving based method is influential on academic achievement, so in answer to the first hypothesis about the effect of problem-solving based methods compared to traditional math achievement, it can be said that there is a statistically significant difference between the means of two groups and subjects of the test group that has been trained using problem-solving based methods, had a higher academic achievement than subjects of the control group who underwent conventional training.

In explaining the findings, we can say that critical thinking and problem solving in nature are the same thing and both are considered a variety of thinking skills. According to Seifert, criticalthinking deals with thinking process and problem-solving deals with product or the result of thought, and many psychologists have proposed the same teaching and learning process for it [14], so considering the characteristics of problem-solving based methods, 
learner-centered, activity in small groups of learning, the facilitating role of the trainer, dealing with the real issues, the problem as a tool for self-regulation and a means of gathering knowledge during learning process, a certain dynamism is created in the classroom, therefore, students who have been trained with this technique and gained a trend that can study regularly an issue from the different perspective with a passion and are more willing to identify various solutions and regular examinations and in general, gain special emotional readiness to deal with complex issues and assignments.

Given that in the problem-solving based methods, students are responsible for their own learning as well as other groups. Therefore, they interact with each other, and they learn better with including in the position of learning and problem solving. On the other hand, the nature of concepts and mathematical topics also facilitates teamwork and by teaching each other and helping poor students, besides improving the learning of average and poor groups also improved their learning. This way of learning to provide an opportunity for thinking, creativity, critical thinking and interactive experience of students with each other and leaves a positive impact on their academic success, something that traditional and direct methods are lacking it.

It should be noted that conclusion about the findings of the first research hypothesis is in line with findings of Khalkhali [13] Fathiazar [16], Slavin [17], Kennedy and Seirafi (quoting from Qodrati, [18]), Khoshbakht [19] and Keramati [20]. Since the research conducted in the academic achievement of math was not enough, in more general state, matters related to academic achievement are used.

\subsection{Second hypothesis}

H0: problem-solving based methods compared to conventional traditional methods has no effect on critical thinking among students.

H1: problem-solving based methods compared to conventional traditional methods had a greater impact on critical thinking among students.

To test this hypothesis, independent t-test and dependent t-test were used. Results are presented using the following tables.

Table 7: Results of Analysis of Levine's Test for Scores of Critical Thinking and Its Components in Students of Test and Control Groups in PreTest

\begin{tabular}{lllll}
\hline Variable & Group & Number & Sig & F \\
\hline Deduction & Control & 90 & 0.21 & 1.45 \\
Identifying assump- & Test & 90 & & \\
tions & Control & 90 & 0.56 & 0.32 \\
& Test & 90 & & \\
Induction & Control & 90 & 0.09 & 2.79 \\
& Test & 90 & & \\
Interpretation & Control & 90 & 0.14 & 2.17 \\
Evaluation of logical & Cest & 90 & & \\
arguments & Test & 90 & 0.08 & 3.03 \\
Total score & Control & 90 & & \\
(Critical Thinking) & Test & 90 & 0.000 & 20.21 \\
\hline
\end{tabular}

To compare mean scores of pre-test of critical thinking and its components in both control and test groups, independent t-test was used. Levene test results in Table (7) showed the equality of variances in the critical-thinking components and inequality of variance in the total score of critical thinking. Assuming equal variances in the components of critical thinking, according to table (8) since the significance level in components (identifying assumptions, inferences, interpretation and evaluation of logical arguments) are greater than the error level 0.05 , so there is no statistically significant difference between the mean scores of pre-test of components (identifying assumptions, inferences, interpretation and evaluation of logical arguments) in both control and test groups, on the other hand, according to the $t$ test results in table
(8) since the significance level in the deduction component is less than 0.05 error level $(0.004<0.05)$, so pretest mean score of deduction in the two control and test groups is the statistically different and mean score of pre-test of deduction in the test group is higher than the control group. Assuming unequal variances in total scores of critical thinking as the significant level of critical thinking in the total score is greater than the error level $0.05(0.05<$ 0.23 ). So there was statistically no significant difference between the mean score of the scores of pre-test the total score of critical thinking in both control and test groups.

Table 8: The Differences in Mean Scores of Critical Thinking and Its Components in Students of Test and Control Groups in Pre-Test

\begin{tabular}{llllllll}
\hline Components & Group & $\mathrm{N}$ & $\mathrm{M}$ & $\mathrm{SD}$ & $\mathrm{T}$ & $\mathrm{DF}$ & $\mathrm{Sig}$ \\
\hline Deduction & Control & 90 & 6.60 & 1.86 & \multirow{2}{*}{2.95} & 178 & 0.004 \\
& Test & 90 & 7.37 & 1.60 & & & \\
Identifying & Control & 90 & 7.36 & 1.83 & 0.32 & 178 & 0.74 \\
assumptions & Test & 90 & 7.27 & 1.79 & & & \\
& Control & 90 & 7.28 & 1.94 & 0.58 & 178 & 0.56 \\
Deduction & Test & 90 & 7.12 & 1.62 & & & \\
& Control & 90 & 7.18 & 2.24 & -0.14 & 178 & 0.88 \\
Interpretation & Test & 90 & 7.22 & 1.82 & & & \\
$\begin{array}{l}\text { Evaluation of } \\
\text { logical argu- } \\
\text { ments }\end{array}$ & Control & 90 & 7.27 & 2.16 & & \multirow{2}{*}{1.07} & 0.28 \\
$\begin{array}{l}\text { Total score } \\
\text { (Critical }\end{array}$ & 90 & 7.59 & 1.82 & & & \\
Thinking) & Control & 90 & 35.66 & 6.19 & & & \\
\hline
\end{tabular}

Table 9: Results of Analysis of Levine Test for Scores of Critical Thinking and Its Components in Students of Test and Control Groups in PostTest

\begin{tabular}{|c|c|c|c|}
\hline Variable & Group & N Sig & $\mathrm{F}$ \\
\hline Deduction & $\begin{array}{l}\text { Test } \\
\text { Control }\end{array}$ & ${ }_{90}^{90} 0.65$ & 0.20 \\
\hline Identifying assumptions & $\begin{array}{l}\text { Test } \\
\text { Control }\end{array}$ & ${ }_{90}^{90} 0.30$ & 1.05 \\
\hline Deduction & $\begin{array}{l}\text { Test } \\
\text { Control }\end{array}$ & ${ }_{90}^{90} 0.48$ & 0.48 \\
\hline Interpretation & $\begin{array}{l}\text { Test } \\
\text { Control }\end{array}$ & ${ }_{90}^{90} 0.69$ & 0.15 \\
\hline Evaluation of logical arguments & $\begin{array}{l}\text { Test } \\
\text { Control }\end{array}$ & ${ }_{90}^{90} 0.29$ & 1.09 \\
\hline $\begin{array}{l}\text { Total score } \\
\text { (Critical Thinking) }\end{array}$ & $\begin{array}{l}\text { Test } \\
\text { Control }\end{array}$ & ${ }_{90}^{90} 0.46$ & 0.53 \\
\hline
\end{tabular}

Table 10: The Difference between Mean Scores of Critical Thinking and Its Components in Students of Test and Control Groups in Post-Test

\begin{tabular}{|c|c|c|c|c|c|}
\hline Components & Group & $\mathrm{N} M$ & SD & $\mathrm{T}$ & DF Sig \\
\hline \multirow{2}{*}{ Deduction } & Test & 907.96 & 1.82 & \multirow{2}{*}{1.008} & \multirow{2}{*}{1780.31} \\
\hline & Control & 907.67 & 2.01 & & \\
\hline \multirow{2}{*}{ Identifying assumptions } & Test & 907.56 & 2.01 & \multirow{2}{*}{0.50} & \multirow{2}{*}{17810.6} \\
\hline & Control & 907.41 & 1.81 & & \\
\hline \multirow{2}{*}{ Deduction } & Test & 908.04 & 1.98 & \multirow{2}{*}{1.10} & \multirow{2}{*}{1780.27} \\
\hline & Control & 907.73 & 1.80 & & \\
\hline \multirow{2}{*}{ Interpretation } & Test & 907.72 & 1.92 & \multirow{2}{*}{-1.10} & \multirow{2}{*}{1780.27} \\
\hline & Control & 908.04 & 1.98 & & \\
\hline \multirow{2}{*}{ Evaluation of logical arguments } & Test & 908.04 & 2.00 & \multirow{2}{*}{0.07} & \multirow{2}{*}{1780.93} \\
\hline & Control & 908.02 & 1.90 & & \\
\hline \multirow{2}{*}{$\begin{array}{l}\text { Total score } \\
\text { (Critical Thinking) }\end{array}$} & Test & 9039.50 & 4.76 & \multirow{2}{*}{1.30} & \multirow{2}{*}{1780.19} \\
\hline & Control & 9038.61 & 4.38 & & \\
\hline
\end{tabular}

To compare mean scores of post-test of critical thinking and its components in both control and test groups, independent t-test was used. Levene test results in Table (9) showed the equality of variances in the components of critical thinking and critical-thinking total score. According to the t test results in Table (10) assuming the equal variances in the components of critical thinking and total scores of critical thinking, since the level of significance in the components of critical thinking and critical-thinking total score is greater than 0.05 error level, so there was statistically no signifi- 
cant difference between the mean scores of the components of critical thinking and critical thinking in both control and test groups.

Table 11: The Differences in the Mean Scores of Critical Thinking and Its Components in Pre-Test and Post-Test

\begin{tabular}{|c|c|c|c|c|c|c|c|c|}
\hline Group & Components & Test & $\mathrm{N}$ & $\mathrm{M}$ & SD & $\mathrm{T}$ & $\mathrm{F}$ & Sig \\
\hline \multirow[t]{12}{*}{ Test } & \multirow{2}{*}{ Deduction } & Pre- test & 90 & 6.60 & 1.86 & \multirow{2}{*}{5.34} & \multirow{2}{*}{89} & \multirow{2}{*}{0.000} \\
\hline & & Post-test & 90 & 7.96 & 1.82 & & & \\
\hline & \multirow{2}{*}{$\begin{array}{l}\text { Assumptions } \\
\text { of recogni- } \\
\text { tion accuracy }\end{array}$} & Pre- test & 90 & 7.36 & 1.83 & \multirow[b]{2}{*}{-0.73} & \multirow[b]{2}{*}{89} & \multirow[b]{2}{*}{0.46} \\
\hline & & Post-test & 90 & 7.56 & 2.01 & & & \\
\hline & \multirow{2}{*}{ Deduction } & Pre- test & 90 & 7.28 & 1.94 & \multirow{2}{*}{-2.81} & \multirow{2}{*}{89} & \multirow{2}{*}{0.006} \\
\hline & & Post-test & 90 & 8.04 & 1.98 & & & \\
\hline & \multirow{2}{*}{ Interpretation } & Pre- test & 90 & 7.18 & 2.24 & \multirow{2}{*}{-1.97} & \multirow{2}{*}{89} & \multirow{2}{*}{0.05} \\
\hline & & Post-test & 90 & 7.72 & 1.92 & & & \\
\hline & \multirow{2}{*}{$\begin{array}{l}\text { Evaluation of } \\
\text { logical ar- } \\
\text { guments }\end{array}$} & Pre- test & 90 & 7.2 & 2.16 & \multirow[b]{2}{*}{-2.93} & \multirow[b]{2}{*}{89} & \multirow[b]{2}{*}{0.004} \\
\hline & & Post-test & 90 & 8.04 & 2.00 & & & \\
\hline & \multirow{2}{*}{$\begin{array}{l}\text { Total score } \\
\text { (Critical } \\
\text { Thinking) }\end{array}$} & Pre- test & 90 & 35.66 & 6.19 & \multirow{2}{*}{6.82} & \multirow{2}{*}{89} & \multirow[b]{2}{*}{0.0001} \\
\hline & & Post-test & 90 & 39.50 & 4.76 & & & \\
\hline \multirow[t]{12}{*}{ Control } & \multirow{2}{*}{ Deduction } & Pre- test & 90 & 7.37 & 1.60 & \multirow{2}{*}{-0.99} & \multirow{2}{*}{89} & \multirow{2}{*}{0.32} \\
\hline & & Post-test & 90 & 7.67 & 2.01 & & & \\
\hline & \multirow{2}{*}{$\begin{array}{l}\text { Identifying } \\
\text { assumptions }\end{array}$} & Pre- test & 90 & 7.27 & 1.79 & \multirow{2}{*}{-0.52} & 89 & 0.59 \\
\hline & & Post-test & 90 & 7.41 & 1.81 & & & \\
\hline & Deduction & Pre- test & 90 & 7.12 & 1.62 & -2.28 & 89 & 0.02 \\
\hline & & Post-test & 90 & 7.73 & 1.90 & & & \\
\hline & Interpretat & Pre- test & 90 & 7.22 & 1.82 & -3.18 & 89 & 0002 \\
\hline & 'PFictatio & Post-test & 90 & 8.04 & 1.98 & - & (3) & 0.002 \\
\hline & Evaluation of & Pre- test & 90 & 7.59 & 1.82 & & & \\
\hline & $\begin{array}{l}\text { logical ar- } \\
\text { guments }\end{array}$ & Post-test & 90 & 8.02 & 1.90 & -1.59 & 89 & 0.11 \\
\hline & Total score & Pre- test & 90 & 36.59 & 4.21 & & & \\
\hline & $\begin{array}{l}\text { (Critical } \\
\text { Thinking) }\end{array}$ & Post-test & 90 & 38.61 & 4.38 & -3.47 & 89 & 0.001 \\
\hline
\end{tabular}

In order to compare the scores of pre-test and post-test of the critical-thinking components and critical-thinking total score, dependent t-test was used in the test group. Because the significance level of components (inference, deduction, interpretation, evaluation of logical arguments) and total score of critical thinking is less than the error level 0.05 , so there is statistically a significant difference between the mean scores of pre-test and post-test (inference, deduction, interpretation, evaluation of logical arguments) and total score of critical thinking in the test group. By observing the means, the mean score of post-test is more than pre-test. Also, because the significance level of components (identification premises) is greater than the error level 0.05 , so there is no significant difference between pre-test and post-test mean scores of components (identification of premises) in the test group.

In order to compare the scores of pretest and post-test of the critical-thinking components and critical-thinking total scores in the control group, dependent t-test was used. Because the significance level of the components (inference and interpretation) and total score of critical thinking is smaller than the error level 0.05 , so there is statistically a significant difference between the mean scores of pre-test and post-test components (inference and interpretation) and total score of critical thinking in the control group By observing means, the mean score of post-test is higher than pre-test. Also, since the significance level of components (inference, recognition of assumptions and valuation of logical arguments) is greater than 0.05 error level, so there is no significant difference between the mean scores of pre-test and post-test components (inference, recognition of assumptions and valuation of logical arguments) in the control group.

Due to the results of differences in pre-test and post-test as well as test and control groups, we conclude that problem-solving based methods are effective on some of the components of critical thinking and critical-thinking total score.

According to the results mentioned in the analytical in this study, the significance of differences between the means of two test and control groups was shown using the t-test. So in answer to the second hypothesis about the effect of the problem-solving based methods compared to conventional traditional methods of students, it can be said that there is statistically a significant difference between the two groups and subjects of the test group that has been training using problem-solving based methods, have higher critical thinking than the control group who underwent conventional traditional methods (confirming research hypothesis and rejecting the null hypothesis).

Therefore, the results of the present study show that the problemsolving method based learning approaches resulted in development and preparedness of critical thinking in inference and interpretation in students, in other words, students who have been trained through problem-solving based learning techniques are more matured in perception, inference and interpretation than those who were trained with traditional methods. On the other hand, problem-solving based methods are not effective on other components of critical thinking, i.e. identifying the assumptions and valuation of logical argument and no significant differences were observed in these parameters in both groups of students.

It should be noted that this result is consistent with the findings of previous research in this field such as Magnussen et al. [6], Young blood and Beitz [7], and Garside [8], Tynjala [9], Babamohadi and Khalili [13], Karabenick and Collins [21], Dennick and Excely [22], Baumberger [23], Norris [24] and Bahmani et al. [25].

\subsection{Extra findings}

To compare the differences between pre-test and post-test mean scores of academic achievement of math and critical thinking in two groups of male and female students, t-test was used. Results showed that there is statistically no significant difference between the mean scores of academic achievement of math, critical thinking between male and female students.

In order to compare the pre-test scores of academic achievement of math and critical thinking in students based on universities (IAU, PNU, HEC) ANOVA test was used. The results indicate that there is a significant difference between the difference of mean scores of pre-test and post-test of critical thinking in the Islamic Azad University and Higher-Education Center $(p=0.001)$ and students' critical-thinking mean score in Higher Education Complex is higher than Islamic Azad University.

\section{Discussion and conclusion}

According to the results presented, it can be concluded that the use of problem-solving based methods, and its various styles can improve the academic achievement of students' critical thinking and help them in achieving educational goals, thinking about the material presented in textbooks, engaging in situations and learning experiences and avoiding rote memorization of content, promoting self-learning ability, critical-thinking skills, promoting systemized learning level, improvement of social and leadership skills, preparing for a role in social activities, a better attitude toward school and learning and more.

This approach while reducing the volume of lectures by teachers in classrooms, can play a guiding role and supervision in the process of teaching and learning and thereby increase the chance of interaction between faculty and students and convert the one-way classrooms to classes full of vitality and conference between teacher and student. In addition, this approach provides learning experience and learning opportunities for students and fields to reduce the volume of problems of non-normative learning and entry into the modern world of technology.

\subsection{Recommendations}

1) Universities and scientific centers are better to hold scientific meetings and workshops and make teachers and educators familiar with the general principles of problem-solving 
based methods, so that they can use in the classroom during training.

2) The teaching method is mostly used in teaching where teaching - learning in them requires the participation and interaction of students and teachers, so that while placing students in problem-solving situations, makes the possibility of interaction between them and teachers and develops the critical-thinking skills and teamwork and collaboration with students and....

3) Learners' critical thinking abilities shapes during study and with the help of teacher, so based on the long-term critical thinking, it is better to start from schools and early years of education.

4) The effects of problem-solving based methods on creative thinking and other social behaviors of students, especially in the society and family should be studied and reviewed.

\section{Acknowledgment}

The authors would like to thank Saravan Branch, Islamic Azad University for the financial support of this research, which is based on a research project contract.

\section{References}

[1] H. Shabani, Educational Skills, Tehran: SAMT (2013).

[2] A. Ahmadi, "Application of problem solving in science education". Journal of Education. 1 (2001); 125-115.

[3] A. A Seif, Modern educational psychology, Tehran: Agah (2013).

[4] C. Myers, "Teaching critical thinking", Translated by khodayar Abili, Tehran: SAMT (2012).

[5] G. B. Watson, and E. M. Glaser, "Watson-Glaser critical thinking appraisal manual, forms A and B", San-Antonio, TX: psychological corporation, (1980).

[6] L. Magnussen, D. Inshida, and J. Itono, "The use of inquiry based learning", J. of Nursing Education, 39, 8 (2000); 360-364.

[7] B. Young and Beitz, "Developing critical thinking with active learning strategies", Nurse Educator, 26 (1) (2001); 39-42 https://doi.org/10.1097/00006223-200101000-00016.

[8] C. Garside, "Look who's talking: A comparison of lecture and group discussion teaching strategies in developing critical thinking strategies", Communication Education, 45 (1996); 212-227. https://doi.org/10.1080/03634529609379050.

[9] P. Tynjala, "Traditional studying for examination versus constructivist learning tasks", Studies in Higher Education, 21, (1998); 185 200.

[10] R. Marzano, et al., "Thinking dimensions in lesson planning and teaching". Translated by Ahghar Qodsi. Tehran: Yastarun (2001).

[11] M. Mehrmohammadi," why should we make the curricula problembase", Quarterly of education, No. 43 and 44, 1995, pp. 10-28

[12] H. Shabani, "Impact of problem solving as teamwork on critical thinking and student achievement in fourth grade (Doctoral dissertation)", Tarbiat Modarres University, Tehran (1999).

[13] H. Babamohammadi, and H. Khalili, "Critical thinking skills of nursing students of Semnan University of Medical Sciences", Iranian Journal of Education in Medical Sciences, Vol. 4, Issue 12 (2004); 29-23.

[14] A. A. Seif, "Effectiveness of learning strategies on reading speed, recall and understanding different texts", Journal of Education, the nineteenth year, 2(2003); 25-39.

[15] D. Walsh, and R. Paul, "The goal of critical thinking: from educational ideal to educational reality", Washington, D. C.: American Federation of Teachers, (1988).

[16] E. Fathiazar, Teaching methods and techniques, Tabriz: Tabriz University Press (2012).

[17] R.E. Slavin, Educational Psychology. Translated by Seyyed Mohammadi, Yahya. Tehran, Ravan (2013).

[18] M. Qodrati, Comparison between the effects of cooperative learning and individual learning in the retention, comprehension, understanding, analysis and scientific judgment in experimental science course in fifth grade class. (Master thesis). Allameh Tabatabai University, Tehran (2001)

[19] F. Khoshbakht, "Effect of collaborative and individual teaching on learning and free recall" (M.A. thesis). University of Shiraz, Shiraz (2001).
[20] M. R. Keramati, Impact of collaborative learning on social skills development and mathematical achievement in fifth grade elementary students in Mashhad in academic year 2002-2003 (Ph.D. dissertation). Teacher Training University, Tehran (2002).

[21] S. Karabenick, and J. Collins-Eaglin, "Relation of perceived instructional goals and incentives to college students' use of learning strategies", The Journal of Experimental Education, 65 (1996); 331 341. https://doi.org/10.1080/00220973.1997.10806608.

[22] R. G. Dennick, K. Exley, (1998), “Teaching and learning in groups and teams" Biochemical Education, 26(1998); 111-115. https://doi.org/10.1016/S0307-4412(98)00028-4.

[23] R. N. Baumberger-Henry, "Cooperative learning and case study: does the combination improve students" Nurse Education Today, vol. (25) Issue (3) (2005); 238-246.

[24] S. D. Norris, "Synthesis of research on critical thinking", Educational Leadership, 42 (4) (1983); 40-45.

[25] M. Bahmani, et al, "Critical thinking skills in basic sciences students in Isfahan University of Medical Sciences", Journal of Medical Education, Vol. 5, Issue 2, (2005); 45-41. 